\title{
The COral-REef Front (COREF) Project
}

\author{
by Yasufumi Iryu, Hiroki Matsuda, Hideaki Machiyama, Werner E. Piller,
}

\section{Introduction}

The First International Workshop on the COral-REef Front (COREF) project was held on 14-19 January 2007 in Okinawa-jima, southwestern Japan to discuss objectives, required laboratory analyses and techniques, potential drilling sites, and scientific proposals for the Integrated Ocean Drilling Program (IODP) and the International Continental Scientific Drilling Program (ICDP). This article briefly introduces the project and reports the outcome of the First International Workshop on the COREF Project.

\section{COREF Project}

The COREF Project (Iryu et al., 2006) involves ocean and land scientific drilling into Quaternary reef deposits in different settings in the Ryukyu Islands (Fig. 1). Major scientific objectives are to examine the following questions:

(1) What are the nature, magnitude, and driving mechanisms of coral-reef front migration in the Ryukyus?

(2) What is the ecosystem response of coral reefs in the Ryukyus to Quaternary climate changes?
(3) What is the role of coral reefs in the global carbon cycle?

To clarify the stratigraphic succession and lithofacies distribution, it is crucial to sample both highstand and lowstand reefs currently ranging from $\sim 200 \mathrm{~m}$ above sea level on the islands to $\geq 150 \mathrm{~m}$ in elevation below sea level on the shelf and shelf slope. To obtain complete stratigraphic coverage, land drilling will need to be combined with ocean drilling.

Secondary objectives include (i) the timing and causes of coral-reef initiation in the Ryukyus, (ii) the position of the Kuroshio Current during glacial periods and its effects on coral-reef formation, and (iii) early carbonate diagenetic responses as a function of compounded variations in climate, eustacy, and depositional mineralogies (subtropical aragonitic to warm-temperate calcitic).

\section{Workshop}

Participating in the workship were a total of twenty-four scientists from seven countries/areas (Austria, French Polynesia, Germany, Japan, Korea, Taiwan, U.S.A.) representing multidisciplinary fields.

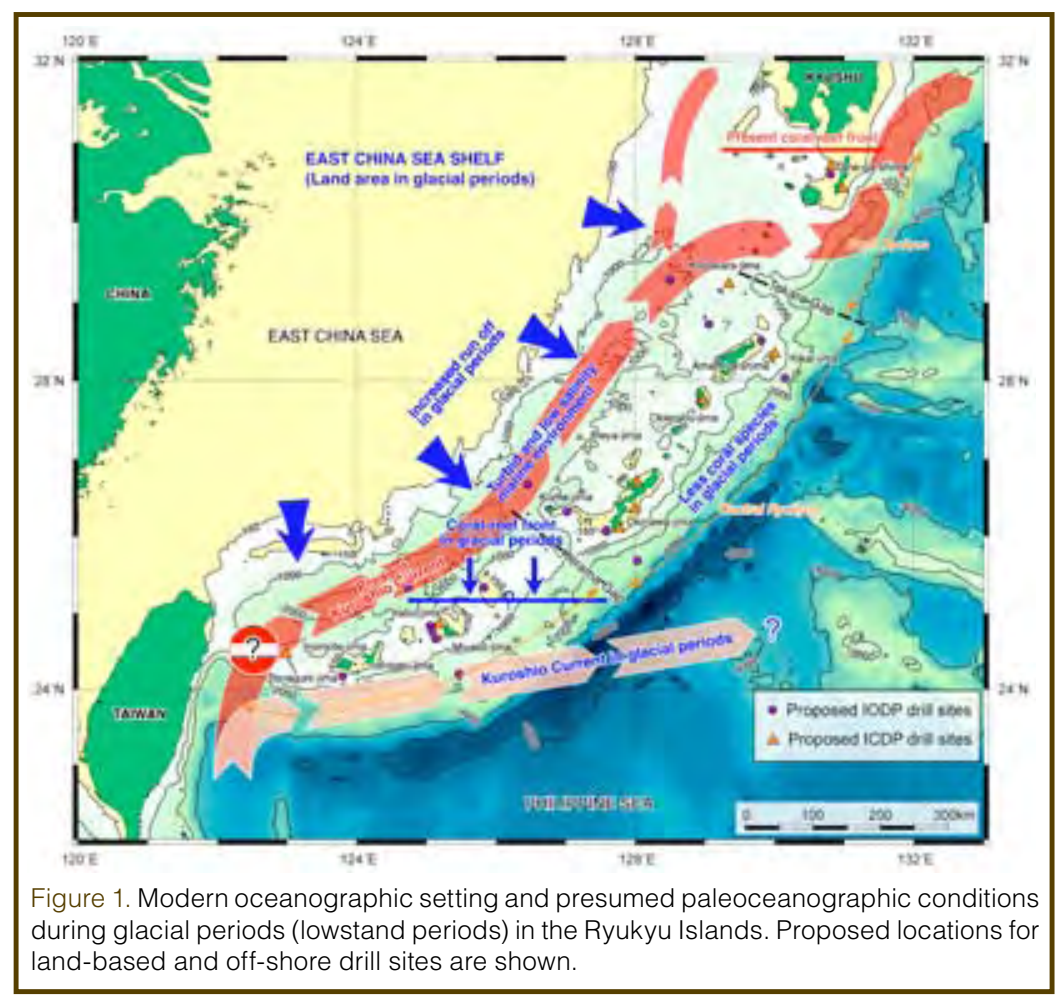

During the first day, a field excursion to an Upper Miocene to Pliocene siliciclastic slope to forearc basin deposits (Shimajiri Group), Pleistocene coral-reef carbonates (Ryukyu Group), and transitional lithofacies (Chinen Formation) illustrated the paleoceanographic transition from the "mud sea" to the "coral sea" (Fig. 2). During the following three days, the geologic setting of the Ryukyu Islands and the stratigraphic scheme of the Plio-Pleistocene carbonate succession were presented in detail, and existing datasets relevant to the COREF Project were reviewed at the Global Oceanographic Data Center of the Japan Agency for Marine-Earth Science and Technology (GODAC/JAMSTEC; http://www.godac.jp/top/en/index.html). Discussions also addressed the regional geologic framework, the availability of biota (corals and foraminifers), diagenetic features as paleoenvironmental proxies, and critical issues related to age determination of the carbonate sequences. 


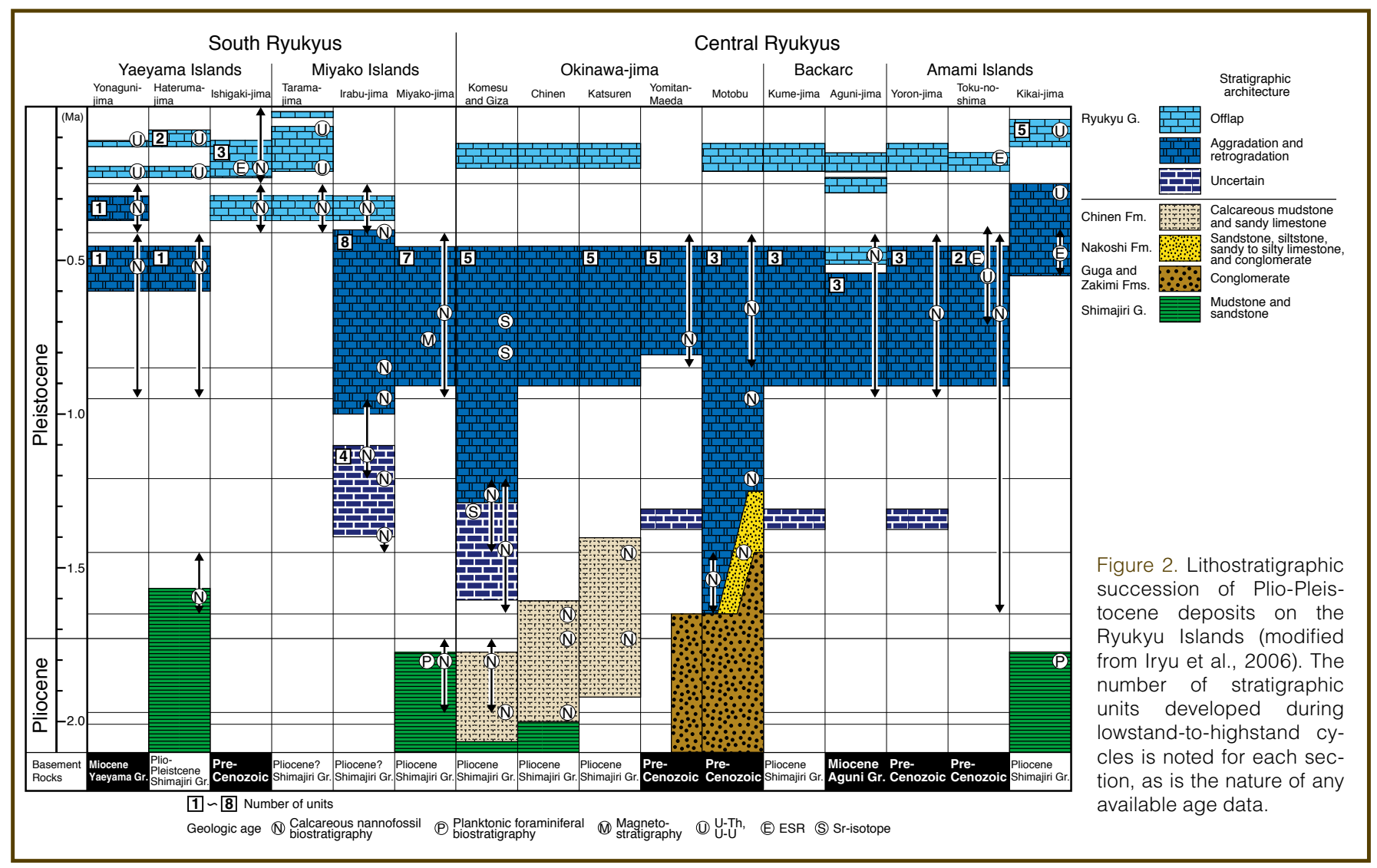

Finally, the workshop participants selected potential drill sites for the COREF Project (Fig. 1).

\section{Major Issues}

Drilling sites: The workshop selected drill sites on transects along and across the Ryukyu Island Arc. The northeast-southwest transect along the Ryukyu Island Arc extends from $24^{\circ} \mathrm{N}$ (south Iriomote-jima) to $31^{\circ} \mathrm{N}$ (west of Tane-gashima), covering islands from subtropical to warm-temperate regions (Fig. 1). The northernmost site is located on the northern limit of the modern coral-reef formation. At present, the distance between areas characterized by reefal coral communities and those by non-reefal coral communities (midway between Amami-o-shima Island and Tane-ga-shima Island; Fig. 1) is approximately $150 \mathrm{~km}$ (for definitions of reefal/non-reefal coral communities, see Veron, 1995). Therefore, the drilling sites on the northeast-southwest transect were designed to be located within an interval $<200 \mathrm{~km}$. Drilling on this transect will provide information on the nature and magnitude of coral-reef front migrations between glacial and interglacial periods. The northwest-southeast transects across the Ryukyu Island Arc are located near Amami-o-shima, Okinawa-jima, and Miyako Islands. These drilling sites are located from proximal (reef) via distal (offreef) parts of ancient carbonate factories to shelf slopes toward the Okinawa Trough and the Ryukyu Trench. These drilling transects will recover a complete stratigraphic succession of the Quaternary carbonate deposits in the Ryukyus at different latitudes.
Coral-reef ecosystem: In the South and Central Ryukyus, corals build extensive fringing reefs dominated by a highly diverse assemblage of acroporid and poritid corals (Sugihara et al., 2003). Conversely, reefs at Tane-ga-shima, near the northern limit of coral-reef distribution, are thin, narrow, sparsely distributed, and dominated by only a few high-latitude coral species (Ikeda et al., 2006). North of the reef front, coral communities are dominated by faviid corals as well as a few other species. The latter are particularly abundant at high latitudes or even endemic to mainland Japan and commonly form large monospecific stands (Japanese Coral Reef Society and Ministry of the Environment, 2004). The compositions of larger foraminiferal assemblages in the North Ryukyus are distinguished from those found in the South and Central Ryukyus by the disappearance of Calcarina gaudichaudii and C. hispida (Sugihara etal.,2006). Nongeniculate coralline algae constitute the third taxonomic key-group emphasized during the workshop, because of their potential use as depth indicators in the fossil record (Iryu, 1992).

Workshop participants stressed the importance of establishing a schematic diagram summarizing the distribution of corals, benthic foraminifers, and coralline algae as a function of bathymetry, irradiance, water energy, and latitude (north and south of the reef front).

Age control: As the main body of the Pleistocene reef and off-reef deposits formed in the Ryukyus before $0.3 \mathrm{Ma}$ (Fig.2), they are beyond the limit of the $230 \mathrm{Th} / 234 \mathrm{U}$ dating method. Thus, biostratigraphy, strontium ( $\mathrm{Sr}$ ) isotope stratigraphy, 
and magnetostratigraphy are the three principal techniques providing chronostratigraphic constraints to carbonate sequences to be recovered during the COREF Project.

Calcareous nannofossil biostratigraphy provides a good chronological constraint to shallow water carbonates (Yamamoto et al., 2006). However, two major problems exist-1) although a high abundance of nannofossils within mixed siliciclastic and carbonate sediments is expected, few fossils may be found from well-indurated and diagenetically altered carbonate rocks, and 2) time resolution of calcareous nannofossil biostratigraphy (twelve datum plains in the Quaternary sequence) is hardly sufficient to resolve the effect on coral reefs of Quaternary glacio-eustatic sea level oscillations. However, precise dating by Sr isotope stratigraphy is possible for shallow water carbonates older than $1 \mathrm{Ma}$ and free of siliciclastic grains/clasts. Magnetostratigraphy is a powerful tool for precise temporal correlation and accurate dating of sediments, even for recrystallized and dolomitized carbonates; however, there are few references on magnetostratigraphic dating and rock magnetic characterization of the Pleistocene carbonate sequences in the Ryukyus. Sakai and Jige (2006) showed that bacterial magnetite minerals in the deposits carry an original depositional remanent magnetization useful for magnetostratigraphic dating.

Multiple techniques, such as electron spin resonance (ESR) and thermoluminescence dating methods, will therefore need to be used to date the samples of the COREF Project.

\section{Towards the Achievement of the COREF Project}

The workshop participants agreed that both land and offshore drilling is required to address the scientific objectives of COREF and that proposals should be submitted to IODP and ICDP for such drilling. A thorough data mining of the literature on the Pleistocene carbonates and their basement rocks, especially Cenozoic sequences in the Ryukyus, is needed because most works were published in local journals with limited distribution. The proponent group welcomes geochemists studying thermoluminescence and ESR dating methods to join the project team.

\section{Acknowledgements}

This workshop was jointly funded by the ICDP and the Japan Drilling Earth Science Consortium (J-DESC). Meeting room and facilities were provided by GODAC/JAMSTEC.

\section{References}

Ikeda, E., Iryu, Y., Sugihara, K., Ohba, H., and Yamada, T., 2006. Bathymetry, biota, and sediments on the Hirota reef, Tanega-shima; the northernmost coral reef in the Ryukyu Islands. Island Arc, 15:407-419, doi:10.1111/j.1440- 1738.2006.00538.x.

Iryu, Y., 1992. Fossil nonarticulated coralline algae as depth indicators for the Ryukyu Group. Transactions and Proceedings of the Palaeontological Society of Japan, New Series, 167:1165-1179.

Iryu, Y., Matsuda, H., Machiyama, H., Piller, W.E., Quinn, T.M., and Mutti, M., 2006. An introductory perspective on the COREF Project. Island Arc, 15:393-406, doi:10.1111/j.14401738.2006.00537.x.

Japanese Coral Reef Society and Ministry of the Environment, 2004. Coral Reefs of Japan. Tokyo (Ministry of the Environment), $356 \mathrm{pp}$.

Sakai, S., and Jige, M., 2006. Characterization of magnetic particles and magnetostratigraphic dating of shallow water carbonates in the Ryukyu Islands, northwestern Pacific. Island Arc, 15:468-475.

Sugihara, K., Masunaga, N., and Fujita, K., 2006. Latitudinal changes in larger benthic foraminiferal assemblages in shallow water reef sediments along the Ryukyu Islands, Japan. Island Arc, 15(4):437-454, doi:10.1111/j.1440-1738.2006.00540.x.

Sugihara, K., Nakamori, T., Iryu, Y., Sasaki, K., and Blanchon, P., 2003. Late Holocene sea level changes and tectonic uplift in Kikai-jima, Ryukyu Islands, Japan. Sediment. Geol., 159:5-25.

Veron, J.E.N., 1995. Corals in Time and Space. Sydney, Australia (University New South Wales Press), $321 \mathrm{pp}$.

Yamamoto, K., Iryu, Y., Sato, T., Chiyonobu, S., Sagae, K., and Abe, E., 2006.Responses of coral reefs to increased amplitude of sea level changes at the Mid-Pleistocene Climate Transition. Palaeogeogr. Palaeoclimatol. Palaeoecol., 241:160-175.

\section{Authors}

Yasufumi Iryu, Institute of Geology and Paleontology, Graduate School of Science, Tohoku University, Aobayama, Sendai 980-8578, Japan, e-mail: iryu@dges.tohoku.ac.jp

Hiroki Matsuda, Department of Earth Sciences, Faculty of Science, Kumamoto University, Kurokami 2-39-1, Kumamoto 860-8555, Japan.

Hideaki Machiyama, Kochi Institute for Core Sample Research, Japan Agency for Marine-Earth Science and Technology (JAMSTEC). Monobe-otsu 200, Nangoku, Kochi 783-8502, Japan.

Werner E. Piller, Institute of Earth Sciences (Geology and Palaeontology), University of Graz, Heinrichstrasse 26, A8010 Graz, Austria.

Terrence M. Quinn, John A. and Katherine G. Jackson School of Geosciences, Department of Geological Sciences, The University of Texas at Austin, 1 University Station C1100, Austin, Texas 78712-0254, U.S.A.

Maria Mutti, Institut für Geowissenschaften, Universität Potsdam-Postfach 60 15 53, D-14415 Potsdam, Germany.

\section{Related Web Links}

http://www.godac.jp/top/en/index.html http://www.dges.tohoku.ac.jp/igps/iryu/COREF/ http://coref.icdp-online.org/ 